\section{Spain to build new cancer research center}

The foundation stone for Spain's largest biomedical research center has been laid. The $\$ 30$ million, 31,000 $\mathrm{m}^{2}$ National Center of Cancer Research (CNIO), which is due to open in 2001, is located on the campus of thelnstituto de Salud Carlos III, M adrid.

TheMinistry of Health, which isfunding thecenter, hopes that CNIO will betheflagship of a new era of Spanish biomedical research. Oncologist Mariano Barbacid, who elucidated the metabolic pathways and mutations of thek-ras oncogene, will direct CNIO which will have an estimated operating budget is $\$ 15$ million and employ around 350 scientists.

Barbacid has been wooed back from the US, where he has worked for 25 years-at the National Cancer Institute from 1974 to 1988 and as vice-president of BristolMyers-Squibb' s Drug Discovery Department from 1988 to 1998-by the "personal challenge" of establishing thecountry'spremier cancer research organization. Barbacid isnow recruiting department headsfor basic research, molecular pathology and experimental therapy.

Mariano Monzó, a leading cancer researcher at the Hospital Germans Trias i Pujol, Badalona, welcomes the new focus on oncology research and says that "the greatest contribution that the CNIO could bring would be to make the latest research technology available to investigators in all parts of the country."

\section{Xavier Bosch, Barcelona}

\section{Corruption in French research charity}

Jacques Crozemarie, the former leader of the French medical research charity, Association for Cancer Research (ARC), has been indicted for embezzlement along with 25 other ARC employees. It is alleged that FF300 million (US\$48.3 million) of the charity's funds were siphoned off during the last five years of Crozemarie's presidency (1990 to 1995).

Crozemarieheaded the ARC for 34 years, during which time some ARC-sponsored biomedical scientists apparently turned a blind eye to the fraudulent activities becauseARC represented theonly source of cancer research funding, according to aJ une 9th article in the French newspaper, Le Monde.

News of the ignominy caused a threefold drop in ARC donations, from FF135 million in 1995 to FF43 million in 1996. Three years later, new president Michel
Lucas finds it hard to regain credibility for thecharity: despitetransparent accounting procedures, and a new administration and board of executives, contributionsare only a fraction of the pre-scandal era (FF47 million in 1998).

In 1995, under Crozemarie's administration, less than one third of the budget went to research projects. The remainderFF268 million-disappeared under the category general expenses. However, ARC now donates three quarters of its total budget to cancer research activities (FF210 million). Crozemarie faces a maximum of 5 years of jail and FF2.5 million fine ( $\$ 415$ million).

Beatrice Renault, New York

\section{Team develops biological computer}

Getting leech neurons to "think" is the basis of a new computational system being developed by a team led by Georgia Institute of Technology professor of Bioengineering Bill Ditto. By adapting the concepts of chaotic computing, Ditto and his colleagues plan to create a computer that uses leach neurons to perform nonlinear calculations. So far, the team has successfully prompted two leech neuronsin a petri dish to add six plus two.

Leech neurons are being used because they are large and relatively well characterized. Ditto and Ron Calabrese, a leech expert at Emory University, Atlanta, intend to have neurons doing computations on a silicon substrate within three years, followed by hybrid neural-silicon chips performing complicated computing problems such as pattern recognition.

Ditto's goal is to develop computers many times smarter than current digital machines. "Why not takeadvantageof the millions of years of evolution of neurons and see if we can incorporate them into a dynamical computer," he asks. Dynamical computing arrives at answers by organizing itself, under reproducible conditions. "If the brain needs to solve a complicated problem, it doesn't go out and buy faster neurons, it just throws moreneurons at the problem and connects them in more creative ways," he explains.

The team accomplished the simple $6+$ 2 addition by attaching electrodes and introducing a current that changes theresting voltage of the cell. By varying voltage, the firing pattern of the neuron can be changed, and numbers can be associated with these changes.

By mimicking the operation of thebrain, Ditto hopes to come up with a system that, much like a person, is adaptable. Yet introducing the human trait of adaptability may also introduce the frailty of temperament, and controlling a feisty leech computer could be a problem.

\section{Victor D. Chase, New York}

\title{
Thailand to regulate animal provision
}

The National Research Council of Thailand (NRCT) is drafting a new "code of conduct" for the use of laboratory animals in biomedical research, in line with intemational standards. With the exception of primate use, which is strictly controlled, the country's animal experimentation remains unregulated. The initiative to draft the guidelines emerged out of an ongoing NRCT campaign to raise standards of conduct in research and to improve overall research quality.

The final draft of the code, which was being prepared as Nature M edicine went to press, requires all universities and research institutes to setup ethics committees and formulate guidelines for animal use. But factions of the Thai scientific community are uneasy with the change. At an academic hearing last March, researchers voiced doubts concerning the practicality and necessity of ethical guidelines for animal experimentation. According to one observer, the situation at many animal facilities in Thailand remains unsatisfactory and some researchers continue to purchase their animals through dubious channels.

But some improvements have been made in the past decade. In particular, the National Laboratory Animal Facility at Mahidol University in Bangkok now supplies 5,000 animals every week to universities and research centers countrywide. Pradon Chatikavanji, retired director of the Mahidol animal facility, and head of the committee drafting the new guidelines, says, researchers urgently need to understand that the quality of their research depends on whether laboratory animals are genetically well-defined and housed in healthy conditions. Roger Lohanen from the Thai Society for the Prevention of Cruelty to Animals, says, "the new guidelines would be the first officially recognized policy that comes close to giving importance to animal welfare."

ROBERT TRIENDL, TOKYO 